\title{
DACA and the Supreme Court: How We Got to This Point, a Statistical Profile of Who Is Affected, and What the Future May Hold for DACA Beneficiaries
}

\author{
Daniela Alulema, Director of Programs, Center for Migration Studies of New York
}

\begin{abstract}
"DACA has changed my life completely. I don't where I would be without the opportunity to receive an education and the opportunity to work legally. I'm proud to be one of the first people in my family to graduate from college. DACA has changed my life, and I hope that it doesn't end with DACA. We need something that will allow us to become residents and eventually citizens because we're part of the United States. Even though we weren't born here, we are part of this country."
\end{abstract}

A 23-year old DACA recipient from Brooklyn, NY

On June 15 2012, President Obama announced the establishment of the Deferred Action for Childhood Arrivals (DACA) program (Napolitano, 2012).1 DACA provides temporary relief from deportation and work authorization to qualifying young immigrants who arrived in the United States as minors. After several failed attempts to pass the DREAM Act, a federal bill that would have provided a path to citizenship to qualifying young immigrants, the announcement of the DACA program provided a much-needed sense of relief, albeit temporary, to thousands of young immigrants who grew up in the United States. Several states subsequently allowed DACA recipients to obtain driver's licenses, state-issued identification, and professional licenses (Gonzales). More broadly, the program opened a floodgate that allowed thousands of young Americans to pursue higher education, better job opportunities, and deepen their social ties in the country.

\section{DACA: Its Requirements and Implementation}

In order to qualify for DACA, recipients needed to meet several requirements and provide onerous documentation (USCIS, 2018). They had to: a) show continuous presence in the United States since June 15, 2007; b) meet certain age limitations (under 31 years of age as of June 15, 2012, arrived in the United States before age 16, and at least 15 years old at the time of the first application); c) physical presence in the United States on June 15, 2012; d) have no lawful status; e) be enrolled in or graduated from high school (which could alternatively be a GED certificate) or be an honorably discharged veteran from the Armed Forces); and f) show good moral character as evidenced by no convictions for a felony, significant misdemeanor, or three or more minor misdemeanors. By applying for DACA relief, applicants trusted the US government with

1 The DACA program resulted from the organizing, leadership, and advocacy of hundreds of immigrant youth and their allies, as well as a political and humanitarian judgement by the Obama administration on the need to offer some relief to this population prior to the presidential election. 
numerous personal details, including their residential history, school location, and workplace. The application required a fee of $\$ 495$, including biometrics, which represented a steep cost for many applicants and their families.2 Recipients were required to renew their work permits every two years in order to maintain their ability to stay in the country without fearing deportation and to work legally.

The DACA program represented a temporary, quasi-legalization program for immigrants in the United States. Like many past legalization programs (Kerwin, 2010), including the far larger Immigration Reform and Control Act of 1986, DACA became a litmus test for immigrant-serving organizations, which had to expand overnight to serve the need of potential beneficiaries. Early estimates by the Center for Migration Studies (CMS) of the potentially DACA-eligible established this group at 1.26 million (Kerwin and Warren, 2016). A CMS study entitled "The DACA Era and the Continuous Legalization Work of the US Immigrant-Serving Community" found that the immigrant-serving sector was able to expand its capacity and redirect staff, assets, resources, and networks of collaborators to meet the demand by DACA recipients (Kerwin et al, 2017). Among other successes, these entities increased the number of immigration attorneys and Board of Immigration Appeals (BIA) recognized agencies and accredited representatives, expanded the number of immigrant-led organizations, fostered greater engagement of program beneficiaries in outreach and advocacy, and made better use of technology and publicly accessible demographic data.

As of June 30,2019, the US Citizenship and Immigration Services (USCIS) had accepted 909,700 initial (first, not renewal) applications between the program's inception in 2012 and 2019 (USCIS, 2019). From this pool, it had approved 825,258 (91 percent) and denied 81,568 (9 percent).

\section{A Statistical Profile of DACA Recipients}

DACA soon proved to be a program of national scope and importance with life-altering impact for its beneficiaries, their families and communities. This next section provides a demographic and social portrait of DACA recipients, which shows their deep level of integration and their extensive ties in US communities. USCIS reported that, as of September 30, 2019, there were 652,880 active DACA recipients (USCIS, 2019a). Fifty-three percent are female. In addition, 66 percent of active DACA recipients are between the ages of 21 and 30 . Figure 1 presents the number of DACA recipients by age bracket. Seventy-six percent reported to be single while 22 percent are married. Figure 2 provides the breakdown of DACA recipients by marital status. DACA recipients are an extremely diverse group who hail from over 158 countries. The top 10 countries of birth for DACA recipients are Mexico (with a vast majority of 80 percent), El Salvador (4 percent), Guatemala (3 percent), Honduras (2 percent), Peru (1 percent), South Korea (1 percent), Brazil (1 percent), Ecuador (1 percent), Colombia (1 percent) and Argentina (1 percent). Map 1 provides an interactive map portraying DACA recipients' countries of origin. DACA recipients reside in all 50 states and US territories including Puerto Rico, Guam and the Virgin Islands. Map 2 shows the number of applicants by state. The top 10 states with the highest number of DACA recipients are California (29 percent), Texas (17 percent), Illinois (5 percent), New York (4 percent), Florida (4 percent), Arizona (4 percent), North Carolina (4 percent), Georgia (3 percent), New Jersey (3 percent), and Washington (3 percent).

\footnotetext{
2 On November 8, 2019, USCIS announced a proposed rule to increase certain immigration benefit fees,
} including DACA which would increase from $\$ 495$ to $\$ 765$ for a renewal request. 


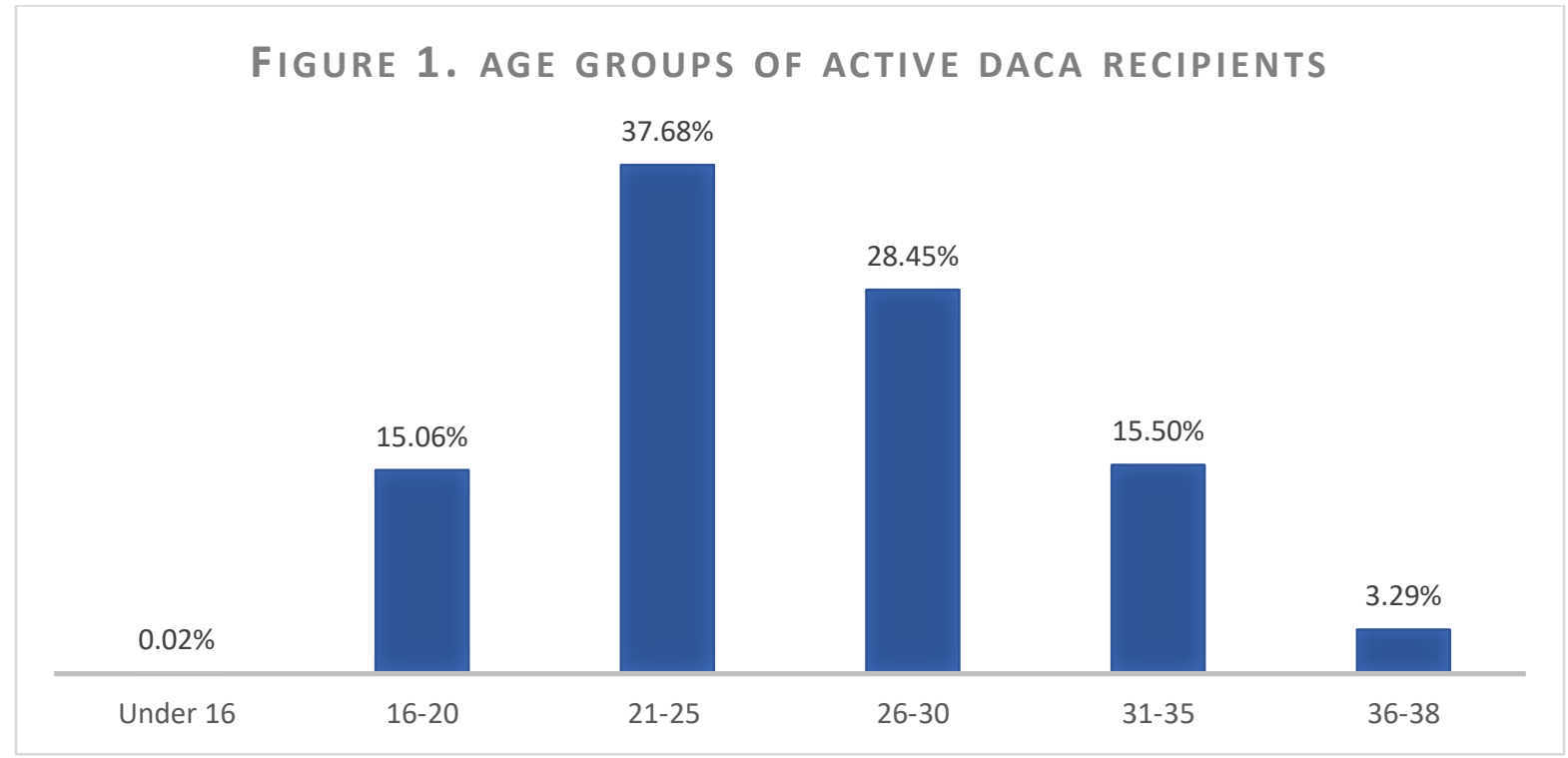

Source: USCIS (2019), figure created by author.

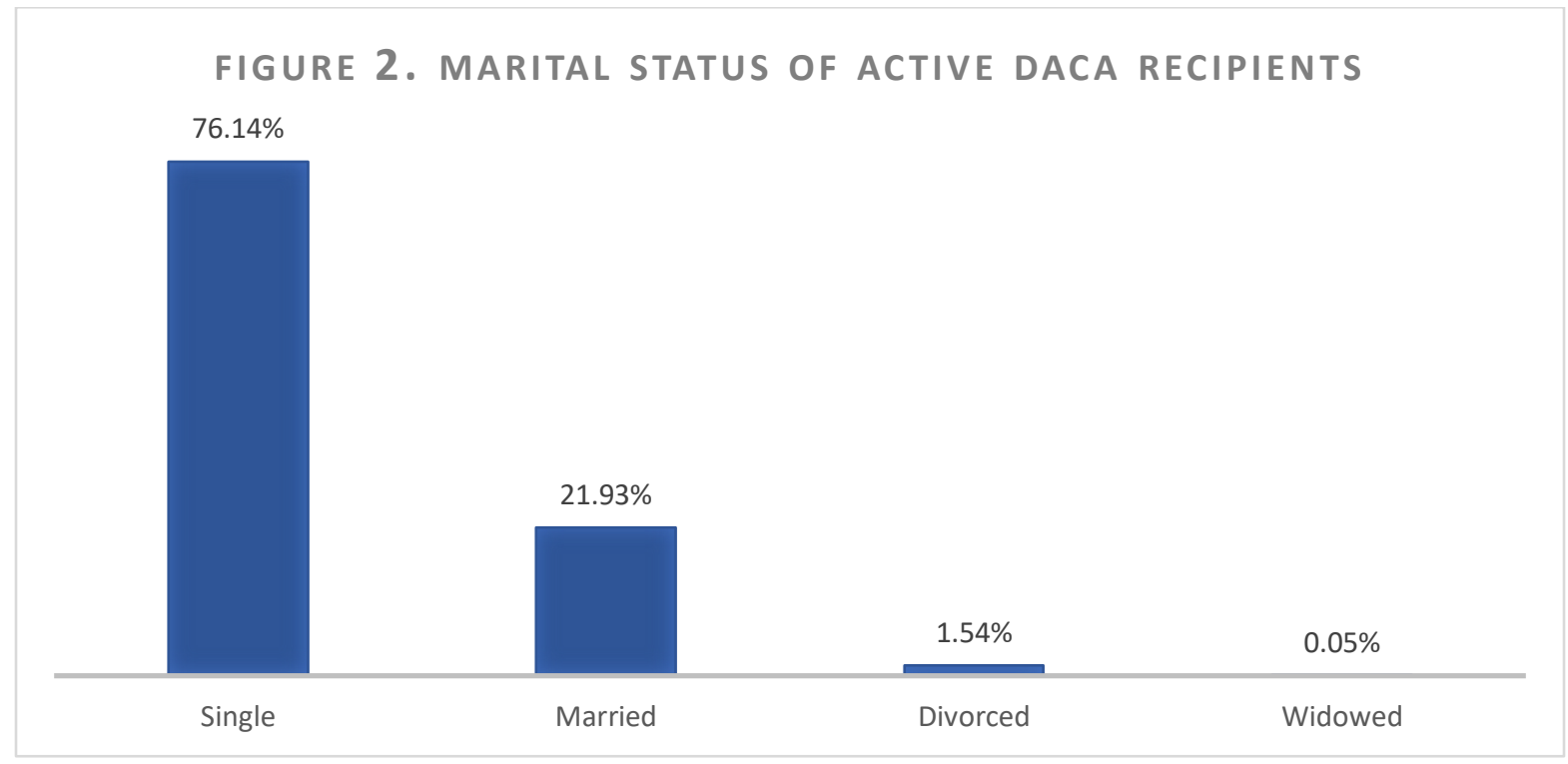

Source: USCIS (2019), figure created by author. 
Map 1. Number of DACA Recipients by Country of Origin

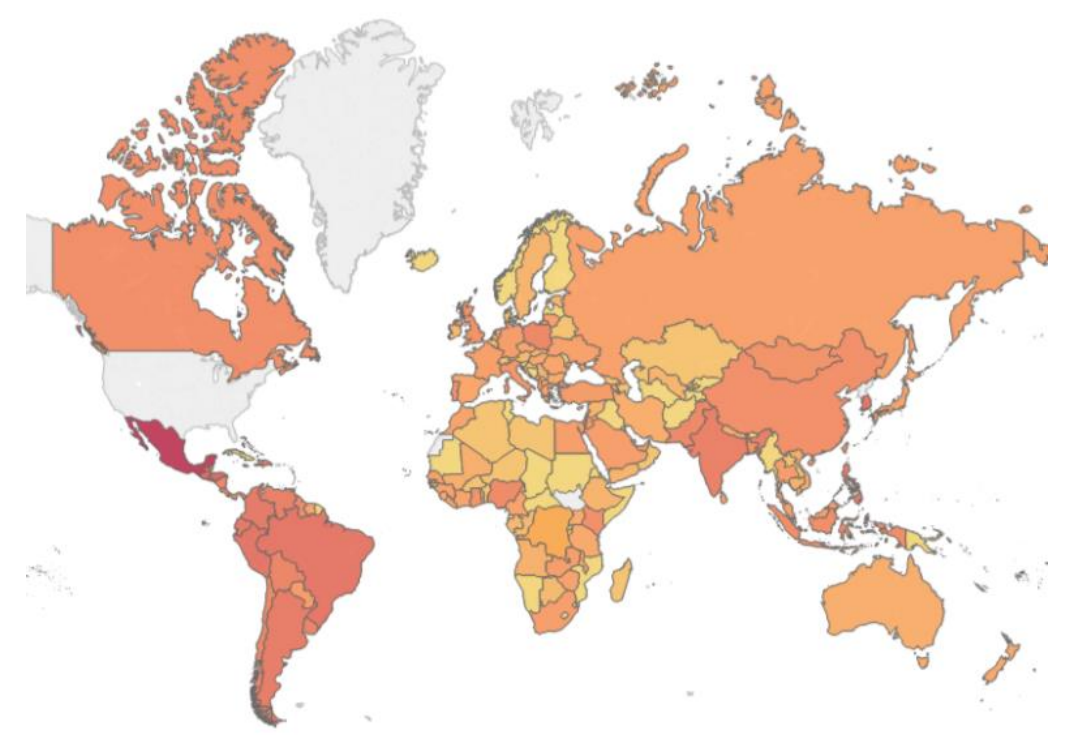

* Not reflected in the map are individuals from the USSR, West Germany, Yugoslavia, and the Netherlands Antilles. Data on country of origin was not available in the electronic systems for 610 recipients.

Source: USCIS (2019), figure created by author.

\section{Map 2. Number of DACA Recipients by State of Residence}

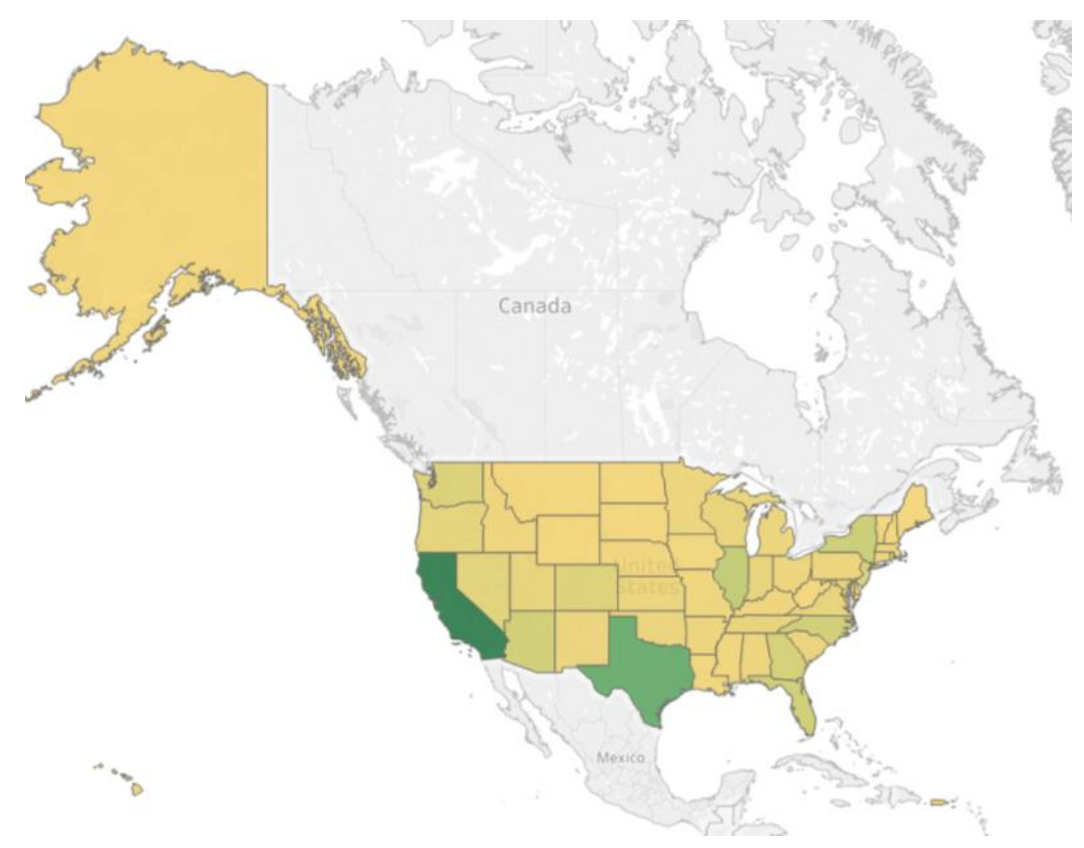

Source: USCIS (2019), figure created by author. 
DACA recipients are deeply integrated in US communities and enjoy longstanding connections to the United States, the country that most of them know as their only home. CMS calculated the following estimates using the 2017 1-year American Community Survey (ACS) data. It selected likely DACA recipients from the pool of 20- to 37-year-olds in 2017 who met the DACA eligibility criteria and combined it with USCIS administrative data on recipients' countries of origin. CMS estimates that 81 percent of DACA recipients has lived in the United States for more than 15 years (Figure 3). Six percent is married to US citizens, four percent to lawful permanent residents (LPRs), and 13 percent to undocumented immigrants. In addition, 346,455 US-born children under the age of 18 have at least one DACA parent. Eighty-eight percent speaks English well, very well, or only English. Figure 4 presents the breakdown of English proficiency among DACA recipients. The great majority speaks at least two languages: 94 percent speaks a language other than English at home. DACA beneficiaries are well-educated: 55 percent graduated from high school, 36 percent has some college education, and 7 percent a bachelor's degree or higher (see figure 5). These rates - which will certainly increase if DACA is preserved and its beneficiaries can advance in legal status - compare favorably to the overall US population, which consists mostly of US citizens. (Morath, 2019; Bier 2018)

FIGURE 3. YEARS IN THE US OF DACA RECIPIENTS

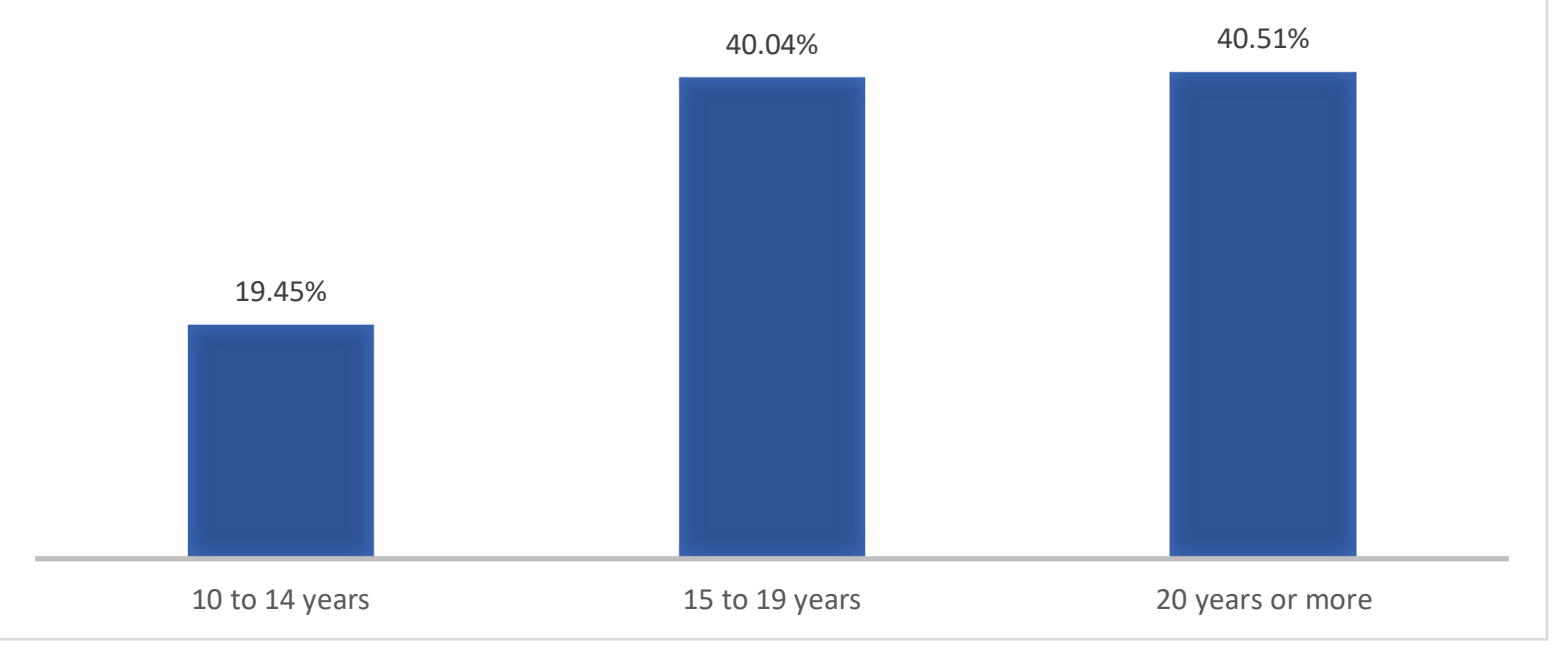

Source: Derived from 2017 ACS data, compiled by CMS. 


\section{FIGURE 4. ENGLISH PROFICIENCY OF DACA RECIPIENTS}

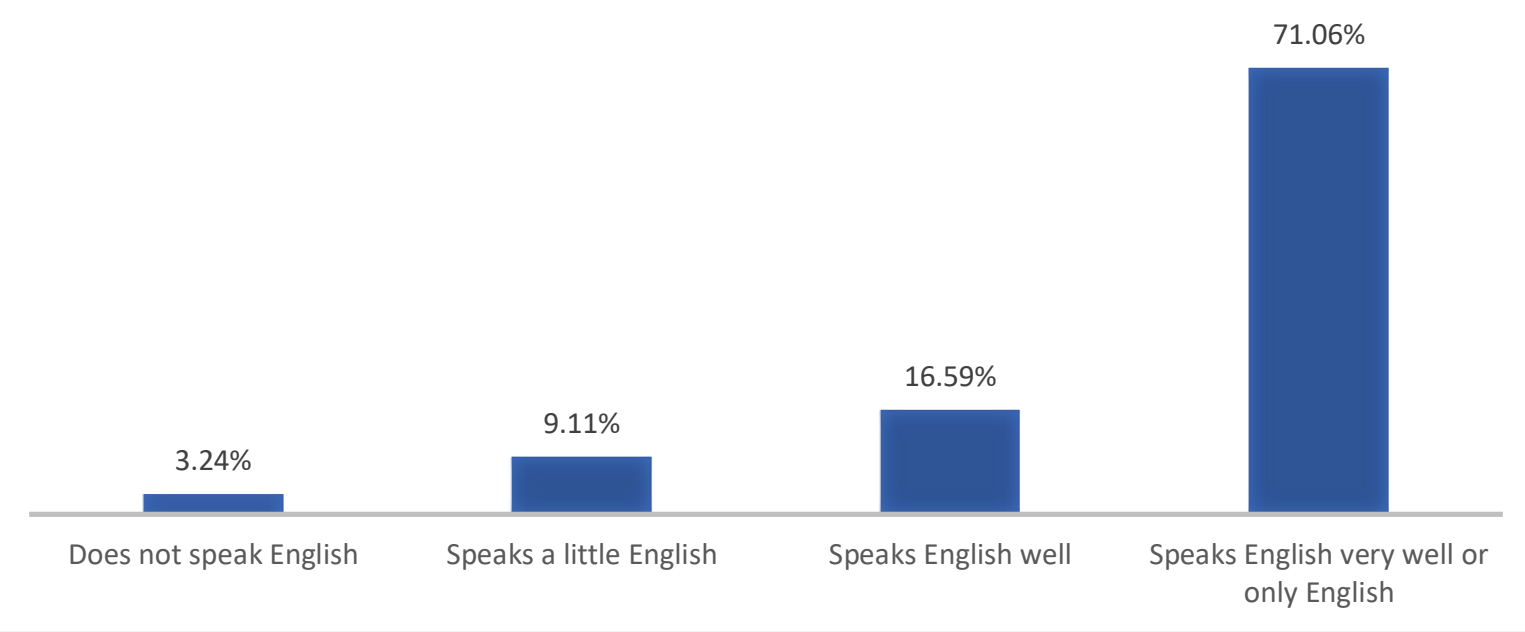

Source: Derived from 2017 ACS data, compiled by CMS.

FIGURE 5. EDUCATIONAL ATTAINMENT OF DACA RECIPIENTS

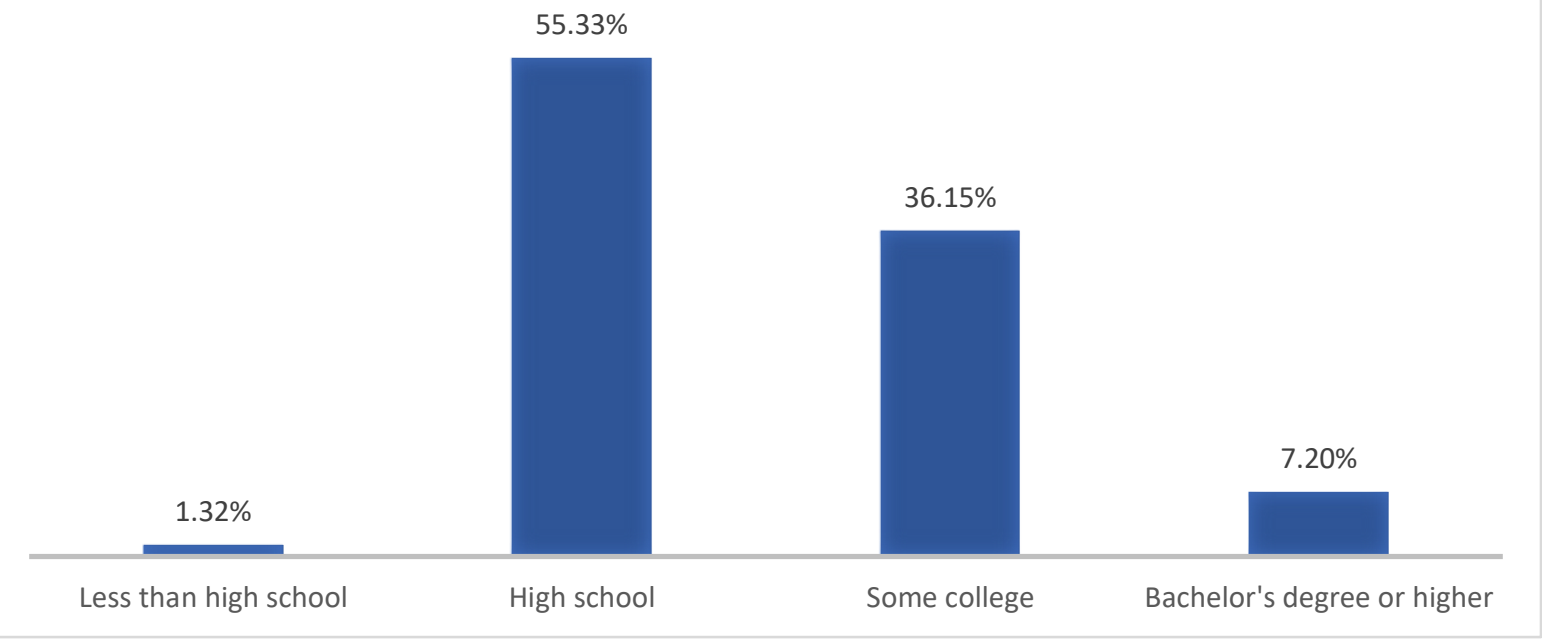

Source: Derived from 2017 ACS data, compiled by CMS.

DACA recipients participate in the US labor market at high rates. According to CMS estimates, 83 percent is in the labor force. From this pool, 95 percent is employed. Five percent of those in the labor force (or 27,100 DACA recipients) is self-employed. Table 1 indicates the top 10 occupational categories in which DACA recipients work. Approximately 88,000 DACA beneficiaries work in skilled occupations. Among those working in skilled occupations, 25,200 DACA recipients work in management, business, and finance, 23,400 as healthcare providers and support, 18,600 in social services, legal, education, arts, and design, and 11,600 in computer, 
math, science and engineering.3 These occupations were selected based on their requirement for advanced degrees and training (Warren, 2018).

Table 1. Top 10 Occupational Categories among Active DACA Recipients, as of September 30, 2019

\begin{tabular}{|ll|}
\hline Occupational Categories & $\begin{array}{l}\text { Number of DACA } \\
\text { Recipients }\end{array}$ \\
\hline Food Preparation and Serving Occupations & 76,100 \\
\hline Office and Administrative Support Occupations & 75,500 \\
\hline Construction and Extraction Occupations & 72,200 \\
\hline Sales and Related Occupations & 66,600 \\
\hline Production Occupations & 52,800 \\
\hline Transportation and Material Moving Occupations & 46,400 \\
\hline Building and Grounds Cleaning and Maintenance & 39,300 \\
\hline Occupations & 24,700 \\
\hline Management, Business, Science, and Arts Occupations & 20,400 \\
\hline Personal Care and Service Occupations & 20,200 \\
\hline Installation, Maintenance, and Repair Workers & \\
\hline
\end{tabular}

${ }^{*}$ Rounded to the nearest 100.

Source: Derived from 2017 ACS data, compiled by CMS.

These figures point to a deeply embedded group of young immigrants who have not only grown up in the United States but are well-rooted in the country and in their local communities through their participation in the labor force, their family ties, and in several other ways.

\section{The Future of DACA}

On September 5, 2017, then-Attorney General Jeff Sessions announced the rescission of the DACA program, arguing that the program was "an unconstitutional exercise of authority by the Executive Branch" (Sessions, 2017). USCIS offered only one month after the announcement for first-time applicants and recipients whose permit expired within September 5, 2017 and March 5, 2018, to apply for or renew their DACA status, leaving hundreds of thousands of DACA recipients with uncertain futures. In response, Congress considered legislative relief for DACA recipients. A bipartisan group of senators introduced the DREAM Act of 2017 (Congress.gov, 2017), which would have provided a path to citizenship to DACA recipients and to Temporary Protected Status (TPS) holders (Bergeron, 2014), but this bill was not brought to a vote by House Speaker Paul

\footnotetext{
${ }^{3}$ Skilled workers are in occupation codes 10 to 3950, Occupation basis in the 2017 ACS.
} 
Ryan or Senate Majority Leader Mitch McConnell. In 2019, Rep. Lucille Roybal-Allard introduced the American Dream and Promise Act (Congress.gov, 2019), which would have provided Dream Act-eligible persons, TPS holders and Deferred Enforced Departure (DED) recipients with a path to permanent legal status. The bill passed the House with a bipartisan majority. However, Senator McConnell refused to bring the bill for a vote, arguing that it should include border security measures.

Several federal lawsuits challenged DACA's rescission, leading to a nationwide preliminary injunction halting the termination of the program (Mira, 2019). As a result, existing DACA recipients have been able to continue submitting applications for renewal as of January 13, 2018. On June 28, 2019, the Supreme Court announced that it would review three legal challenges, Regents of the University of California v. DHS, Batalla Vidal v. Nielsen, and NAACP v. Trump, and would hear arguments in these cases on November 12, 2019 (Mira, 2019). The National Immigration Law Center has charted possible outcomes of the litigation (NILC, 2019). The Supreme Court's ruling will determine how and whether the DACA program can continue.

It is important to note that the rescission of the DACA program in 2017 not only affects the 652,800 current DACA recipients, but also the new generation of undocumented immigrants who were too young to apply for the program when it was still valid. According to estimates by the Migration Policy Institute, 98,000 undocumented students graduate from high school every year (Zong and Batalova, 2019). Undocumented immigrants who were younger than 15 , the required age to apply for DACA, were left out of the program due to its cancellation in 2017. Since then, thousands of young undocumented immigrants have faced limited work and education opportunities and have been at risk of removal. The Supreme Court will issue a decision on the case between January and June 2020, likely towards the end of this period in the midst of the presidential campaign.

\section{The Impact of DACA}

The DACA program provided myriad opportunities to its recipients that range from better-paying jobs, access to higher education, an increased sense of belonging, and improved mental health. DACA recipients perceived an increased sense of agency as a result of the program: They finally could decide whether to invest in their education, advance in their careers, or access jobs to become self-sufficient. To humanize the statistics, CMS interviewed several DACA recipients in the New York metro area on DACA's impact in their lives and what its termination would entail. They emphasized that DACA allowed beneficiaries to pursue academic opportunities. One recipient said, "I'm definitely proud to be one of the first people in my family to graduate from college. DACA has changed my life." Another recounted that "June 15, 2012 will be a day I will never forget. I remember that I began crying when I heard that DACA was signed. I didn't understand the limitations of it at that point, but I understood that it would allow me to at least pay for my education, and to at least see that dream through." These testimonies were consistent with a study from the National Bureau of Economic Research which found that DACA "significantly increased high school attendance and high school graduation rates, reducing the citizennoncitizen gap in graduation by 40\%" (Kuka et al, 2018).

DACA also allowed immigrant youth to work in occupations and industries better aligned with their area of study and interest. One interviewee stated, "DACA has definitely motivated me to go down an educational path and motivated me to go to college and eventually graduate. DACA pushed me to get my degree in education because I do eventually want to be a full-time teacher. I'm planning to get all my certification exams done to eventually apply for a full-time job at the 
Department of Education and have my own classroom, with my own students, who I could dedicate a whole year to, and help them reach their fullest potential. Help them read, help them learn, help them become global citizens." Another DACA recipient stated, "I always knew I liked science and math. In college, I became involved in the immigrant rights movement, which opened my eyes to a lot of social injustice. Initially I thought 'well, medicine isn't really about social justice or creating social change.' But then I realized that there are so many doctors who work in that area and can actually make a difference. I wanted to go into medicine to work with people like my parents, serving them, providing healthcare for them and other underserved, marginalized communities."

An important benefit of DACA was the access it offered to "advance parole," which allowed certain applicants to travel outside the United States. Advance parole applicants could petition the government to allow them to travel for humanitarian, employment or educational reasons, knowing they could return to the United States. The program allowed DACA recipients to travel outside the United States if, for instance, they needed to visit an ill family member, attend a work conference, or study abroad. The petitioner had to specify strict exit and entry dates and needed to provide extensive evidence to be approved for this program. A recipient expressed, "[DACA allowed me] to apply for advance parole. I was able to go back to Ecuador and see my grandma. It was one of the most amazing experiences l've had. DACA made that possible."

DACA has allowed individuals to become more active and contributing members of their communities. For instance, a DACA recipient who attends Rutgers University stated, "DACA has helped me a lot. It allows me to drive, to go to federal buildings so that I can interpret for people at their asylum claim. It allows me to be an advocate for others. It's helped the fear and given me visibility." Studies report that one of the side benefits of legalization programs like DACA is the sense of safety and stability that they afford, which consequently improve the mental health of its beneficiaries and offers other health benefits. A survey analysis conducted by Patler et al (2019) found that the security and protections of the DACA program had a positive effect on DACA recipients' health. The program will also likely have a positive impact on the children and other family members of DACA recipients. One study, for example, documented the inter-generational impact of protecting unauthorized immigrants from deportation. The study reports that "parents' unauthorized status is a substantial stressor that stymies normal child development and perpetuates health inequalities by transferring parental disadvantages to children. [...] Early childhood exposure to stress and adversity does not only cause poor health and impaired development in the short term; the issues can also persist into adulthood" (Hainmueller, 2017).

The rescission of the DACA program has produced stress and anguish among DACA recipients as they are faced again with living in a legal limbo and an uncertain future. A DACA recipient said, "I tend to worry a lot now. I don't know what's going to happen next. It does affect my emotional state to be constantly worried. My work authorization expires in October of next year, and I know that I can work until October, but I don't know what is going to happen after that." Another one stated, "(when) Trump became president, it was very scary. I actually had a really hard time during the second semester of my first year of med school because of it, and I actually ended up failing a class. I wasn't able to focus very well."

If the Supreme Court allows the full rescission of the DACA program, thousands of young immigrants would lose their jobs and would be at risk of deportation. An interviewee stated: "The government has our information, and they know where we live. We don't know what they are going to do with that information. Also, I won't be able to continue working as a substitute teacher. 
It's going to be devastating not to be able to do what I love." By losing DACA, the United States would potentially lose productive members of its labor force to jobs that under-utilize them or to migration to other countries. A DACA recipient said that if the program ends, she would return to "jobs that don't require work authorization. I would do waitressing jobs or cleaning jobs. I've done that before." Another interviewee mentioned, "if I finish my residency in three years and things don't change or DACA is taken away, I would definitely consider leaving the country."

DACA opened the door to over 652,880 young immigrants who are Americans in every way but legal status. Multiple polls show that most Americans want a path to citizenship for these undocumented young immigrants (Global Strategy Group, 2019). This support has been also been demonstrated through the numerous amicus briefs filed in support of DACA recipients, representing a wide range of entities including state and local governments, national networks, IT companies, national organizations, higher education institutions, business associations, law enforcement leaders, former and current congressmen, legal scholars, educational organizations, former national security experts, labor unions, administrative law practitioners, military and veteran advocacy organizations, and religious organizations (SCOTUSblog, 2019).

\footnotetext{
"Being a DACA recipient is really hard, honestly. It's an anxiety I and others live with every day. DACA gave me hope and made me feel like we finally fit in. It has helped me and my family financially with jobs we wouldn't be able to have if DACA ends. It helped us set goals and see beyond. I feel like I'm creating all of these memories with my family, but then I remember that it may all be over. It's bittersweet."
}

A DACA recipient and mother of a 9-year-old US citizen child

\section{Recommendations}

DACA recipients are contributing members integrated in the fabric of US society as demonstrated by this statistical profile and the testimonies from a select group of beneficiaries. After several years of organizing, advocating, and coming out of the shadows, undocumented young immigrants were able to obtain temporary relief through the DACA program. In the seven years that the program has existed, they have strengthened their bonds to a nation that received them when they were children yet has not been willing to recognize legally what they are in fact Americans.

During the next few weeks, the Supreme Court should consider the numerous contributions made by undocumented immigrants and their deep connections to the United States. Advocates and allies should fortify their commitment to accompany, defend, and empower this group of young immigrants by expressing their vocal support to elected officials and among their own constituencies. State and local policymakers and immigrant-serving organizations should consider implementing and supporting policies, such as in-state tuition, state-funded financial aid, and access to state-issued identification and professional licenses, to undocumented young immigrants, including DACA recipients and those who did not get an opportunity to apply for the program. At the federal level, Congress should enact permanent protection that offers a path to 
citizenship to the undocumented community that day by day continues to live and contribute in our workplaces, schools, neighborhoods and houses of prayer. Until the administration and Congress stop making immigration a hot-button political issue and stop treating immigrants as bargaining chips, the Supreme Court will have the future of hundreds of thousands of young undocumented immigrants in its hands. It should act wisely and justly.

"I've been able to pay my taxes for the last six years. I was able to buy a car, pay my tuition, earn the money that I've been spending. I can see that although those things have been beneficial for me, they have also been beneficial for the overall financial well-being of my community. The best advice for people in my situation is to remember that a work permit does not define who you are. I know it affects the opportunities you have, but we are still going to be here even if it isn't valid anymore."

A DACA recipient and law student at Rutgers University

\section{A note on methodology}

The total number of DACA recipients, state subtotals, and nationality subtotals are presented as the USCIS report on approximate DACA recipients as of September 30, 2019. CMS estimated the characteristics of DACA recipients by randomly selecting from the DACA-eligible pool using per-country administrative data from USCIS. The USCIS report shows 760 individuals as having "unknown" country of origin. They are, therefore, not included in this report.

The author thanks the Center for American Progress for sharing the USCIS report on active DACA recipient as of September 30, 2019, and Mike Nicholson and Bob Warren for calculating the CMS estimates based on the 2017 American Community Survey. She also thanks the DACA recipients who shared their lived experiences, aspirations and concerns.

\section{References}

Bergeron, Claire (2014). "Temporary Protected Status after 25 Years: Addressing the Challenge of Long-Term 'Temporary' Residents and Strengthening a Centerpiece of US Humanitarian Protection." Journal on Migration and Human Security 2(1): 22-43. https://cmsny.org/publications/jmhs-temporary-protected-status-after-25-years/

Bier, David. (2018) "Family \& Diversity Immigrants Are Far Better Educated Than U.S.-Born Americans." CATO Institute. January 25, 2018. https://www.cato.org/blog/family-diversityimmigrants-are-far-better-educated-us-born-americans

Congress.gov (2017). "S. 1615 - DREAM Act of 2017." 115th Congress. https://www.congress.gov/bill/115th-congress/senate-bill/1615

Congress.gov (2019). "H.R.6 - American Dream and Promise Act of 2019." 116th Congress. https://www.congress.gov/bill/116th-congress/house-bill/6 


\section{DACA and the Supreme Court}

Global Strategy Group (2019). "New Survey - Voters nationwide overwhelmingly support citizenship bill for Dreamers." https://www.fwd.us/wp-content/uploads/2019/05/FWD.usDreamer-Bill-Memo.pdf

Gonzales, Roberto, Benjamin Roth, and Kristina Brant. "The Growing Significance of Place: Assessing the Diverging Trajectories of DACA-eligible Young Adults in the New South." Oakland, CA: University of California Press. https://cmd.princeton.edu/sites/cmd/files/resourcelinks/the_growing_significance_of_place___gonzales_roth_and_brant.pdf

Hainmueller, Jens, Duncan Lawrence, Linna Martén, Bernard Black, Lucila Figueroa, Michael Hotard, Tomás R. Jiménez, Fernando Mendoza, Maria I. Rodriguez, Jonas J. Swartz, and David D. Laitin (2017). "Protecting unauthorized immigrant mothers improves their children's mental health." Science. 08 Sep 2017 : 1041-1044.

https://science.sciencemag.org/content/357/6355/1041

Kerwin, Donald (2010). "More than IRCA: U.S. Legalization Programs and the Current Policy Debate." Washington, DC: Migration Policy Institute. December 2010. https://www.researchgate.net/publication/284360938_More_than_IRCA_US_Legalization_Progr ams_and_the_Current_Policy_Debate/link/5ab3bbccaca272171002f308/download

Kerwin, Donald, Roberto Suro, Tess Thorman and Daniela Alulema (2017). "The DACA Era and the Continuous Legalization Work of the US Immigrant-Serving Community." New York, NY; Center for Migration Studies. https://cmsny.org/wp-content/uploads/2017/02/CMS-LegalizationReport-FINAL.pdf

Kerwin, Donald, and Robert Warren (2016). "Potential Beneficiaries of the Obama Administration's Executive Action Programs Deeply Embedded in US Society." 2016. Journal on Migration and Human Security 4(1): 16-28.

https://journals.sagepub.com/doi/pdf/10.1177/233150241600400102

Kuka, Elira, Na'ama Shenhav, and Kevin Shih (2018). "Do Human Capital Decisions Respond To The Returns To Education? Evidence From DACA." National Bureau of Economic Research. February 2018. https://www.nber.org/papers/w24315.pdf

Mira, Ilissa (2019). "Multiple Lawsuits Challenge DACA Rescission." Catholic Legal Immigration Network, Inc. July 17, 2019. https://cliniclegal.org/resources/multiple-lawsuits-challenge-dacarescission

Morath, Eric (2019). "Foreign-Born Workers Make Up Highest Percentage of U.S. Employment Since 1996." The Wall Street Journal. May 16, 2019. https://www.wsj.com/articles/foreign-bornworkers-make-up-highest-percentage-of-u-s-employment-since-1996-11558021429

Napolitano, Janet (2012). "Exercising Prosecutorial Discretion with Respect to Individuals who Came to the United States as Children" Memo. June 15, 2012.

https://www.dhs.gov/xlibrary/assets/s1-exercising-prosecutorial-discretion-individuals-whocame-to-us-as-children.pdf

National Immigration Law Center (2019). "DACA Heads To The U.S. Supreme Court: Where We Are Now \& What Could Happen Next." https://www.nilc.org/issues/daca/daca-heads-toscotus-scenarios/ 
Patler, Caitlin, Erin Hamilton, Kelsey Meagher, and Robin Savinar (2019). "Uncertainty About DACA May Undermine Its Positive Impact On Health For Recipients And Their Children" Health Affairs. 38:5, 738-745. https://www.healthaffairs.org/doi/full/10.1377/hlthaff.2018.05495

SCOTUSblog (2019). Department of Homeland Security v. Regents of the University of California. https://www.scotusblog.com/case-files/cases/department-of-homeland-security-vregents-of-the-university-of-california/.

Sessions, Jeff (2017). “Attorney General Sessions Delivers Remarks on DACA.” US Department of Justice. https://www.justice.gov/opa/speech/attorney-general-sessions-deliversremarks-daca

US Citizenship and Immigration Services (2018). Frequently Asked Questions. https://www.uscis.gov/archive/frequently-asked-questions. March 8, 2018.

US Citizenship and Immigration Services. "Number of Form I-821D, Consideration of Deferred Action for Childhood Arrivals by Fiscal Year, Quarter, Intake and Case Status." Accessed November 1, 2019.

https://www.uscis.gov/sites/default/files/USCIS/Resources/Reports\%20and\%20Studies/Immigra tion\%20Forms\%20Data/Static_files/DACA_FY19_Q3_JUNE_FINAL.pdf

US Citizenship and Immigration Services (2019a). "Approximate Active DACA Recipients as of September 30, 2019." File is with author.

Warren, Robert (2018). "The Legally Resident Foreign-born Population Has the Same Percentage of Skilled Workers as the US-Born Native Population.” January 31, 2018. https://cmsny.org/publications/foreign-born-same-skilled-native/

Zong, Jie and Jeanne Batalova (2019). "How Many Unauthorized Immigrants Graduate from U.S. High Schools Annually?" Migration Policy Institute. April 2019.

https://www.migrationpolicy.org/research/unauthorized-immigrants-graduate-us-high-schools 